\title{
Cross-cultural Competence and Its Formation in Future Officers of the National Guard of Ukraine
}

\author{
Iryna Sevruk ${ }^{1}$ Yulia Sokolovska $^{1}$ Natalia Chuprinova ${ }^{1, *}$ Yuliia Khoroshylova $^{1}$ \\ ${ }^{1}$ National Academy of the National Guard of Ukraine, Ukraine \\ *Corresponding author. Email: chuprinova_n@ukr.net
}

\begin{abstract}
The article aims at substantiating the need to develop cross-cultural competence in future officers of the National Guard of Ukraine under conditions of rapid development of multiculturalism in the Ukrainian society and to present a project on building the competence within interdisciplinary environments. Theoretical basis of the study: fundamental researches of national and foreign experts on the problems of cross-cultural communication as well as modern papers on building cross-cultural competence within the educational process. Methodological basis: cross-cultural, concrete historical, systemic, hermeneutic and interdisciplinary approaches. Research methods: philosophical reflection, analysis, synthesis, document analysis, monitoring, observation, survey and social experiment. The context of the study is higher military education the National Academy of the National Guard of Ukraine provides to future officers. The results obtained in the course of the study are distinguished by their originality: 1) the need to form cross-cultural competence in future officers of the National Guard of Ukraine was substantiated; 2) tolerance and equality were substantiated for being an axiological basis of social communications in a multicultural space since they build a strong core of cross-cultural competence acquired by future law enforcement officers; 3) the issue of moral choice in cross-cultural interaction in the context of social communication is considered; this goes beyond the study limited to only interpersonal interaction (ethics of possibility, I. Donnikova); 4) a study of tolerance in the cadet environment was made and a comparative analysis of the obtained research results on tolerance among students (W. Zheyuan) and cadets (authors of the paper) was carried out; 5) cross-cultural competence of cadets proved to build only within the educational process; 6) a project on implementing the objective to build cross-cultural competence in future officers of the National Guard of Ukraine was presented. Conclusions: 1) successful performance of the National Guard of Ukraine within a multicultural environment depends on the ability of law enforcement to be impartial and objective and make decisions based on the values of cross-cultural tolerance, recognition of equality of all participants in social communication regardless of their cultural affiliation, non-discrimination and non-discrimination; 2) an interdisciplinary approach can provide a comprehensive development of cross-cultural competence in future officers of the National Guard of Ukraine within the existing educational and professional programs; the unity of the cross-cultural approach in teaching socio-humanitarian disciplines may provide complexity in building crosscultural competence; 3) interactive methods of developing cross-cultural competence are effective; 4) it is necessary to change conceptual approaches to training future officers of the National Guard of Ukraine and overcoming obsolete attitudes and stereotypes. Perspective directions of solving the problems noted in the research are outlined.
\end{abstract}

Keywords: social communications, cross-cultural communication, cross-cultural competence, globalization, tolerance, educational process, officer of the National Guard of Ukraine.

\section{INTRODUCTION}

We must recognize that social reality is changing very rapidly under modern conditions. Ukraine emerges as a space where, along with the processes of national self-determination and national selfidentification, the processes caused by globalization are unfolding, in particular, increased labour migration, internationalization of education, different 
forms of integration, etc. This inevitably leads to cultural diversity within social groups where social communications can (and will) occur in the course of performing official and combat tasks assigned to units of the National Guard of Ukraine (NGU).

The specificity of the tasks is that all of them (except for participation in international missions) are performed in Ukraine, in a certain socio-cultural environment. This situation often gives rise to misconceptions about the cultural homogeneity of social communications that occur when NGU units fulfil their assignment.

However, considering the current trends of globalization in Ukraine and the dynamics of migration and demographic processes in the country, the tasks of the NGU will most likely be set in a multicultural space in the next 10 to 15 years.

Thus, as fundamentally important, there is a problem of developing the ability of NGU servicemen, primarily officers, to establish optimal social interactions with different social groups, taking into account cultural differences and the diversity of these groups. And this requires building cross-cultural competence in future officers of the NGU as the ability to notice and understand common things and differences between cultures and to recognize all participants of social interaction as equal subjects. This is what ensures impartiality, objectivity, compliance with the norms concerning social equality and justice, and prevention of discrimination in crosscultural communication.

At the same time, we should note that the problem of building cross-cultural competence in the military is still attention-seeking. The provision of some knowledge on the specifics of cross-cultural interaction takes place within the framework of preparing the military to perform tasks in international missions. But today's Ukraine is already being shaped as a multicultural space.

The above mentioned purpose of the article is closely connected with the analysis and theoretical justification for the significance of building crosscultural competence in future NGU officers since it forms the basis for social communications in the course of their service and combat missions, finding ways to implement the task on building personal crosscultural competence in future officers through the educational process at the National Academy of the National Guard of Ukraine.

\section{PROBLEMS AND METHODOLOGY}

The methodological basis of the study comprises the systemic, interdisciplinary, concrete-historical, cross-cultural, and hermeneutic approaches. The systemic and concrete-historical approaches are universal in the methodology of modern scientific knowledge. Cross-culture appears as a methodological prerequisite that ensures the development of humanitarian knowledge in the modern multicultural world. The optics of the hermeneutic approach allows optimizing cross-cultural communication by refusing to absolutize any culture at both individual and general cultural levels. The interdisciplinary approach significantly expands the possibilities of theoretical search for solutions to building cross-cultural competence in the educational process. The study used methods of philosophical reflection and analysis, including comparative, synthesis, and document analyses, monitoring, observation, survey and social experiment.

The theoretical basis is the fundamental scientific work of national and foreign experts in the field of cross-cultural communication and cross-cultural / cross-cultural competencies. Given the objectives of the article, practically significant are modern studies on building cross-cultural competence within the educational process (F. Step, W. Bowles and D. Bridges [10], W. Zheyuan [12], K. Puntey [2], L. B. Perry and L. Southwell [3]) and analyses of the moral and ethical basis for cross-cultural communication (I. Donnikova [4]).

There is a list of materials used in the course of the study: Constitution of Ukraine, Sustainable Development Goals: Ukraine. National Report 2017, Law "On the National Guard of Ukraine", State education standards of the higher professional education approved for specialties 253, 254 and educational and professional training programs (Bachelor's Degree) developed on their basis at NANGU.

Analysis of researches and publications. The problem of building cross-cultural / multicultural competence in future professionals appears today as quite relevant. At the same time, the existing works of foreign and national researchers focus on studying the problem in the context of professional training for future teachers, managers, and social workers. Building cross-cultural competence in future officers of the National Guard of Ukraine is still seeking attention from national experts who could share their theories. 
The study applies the basic categories of the theory of cross-cultural communication (cross-culturality and multiculturalism) developed since its inception and to date. Methodologically significant within the framework of this study is the fundamental attitude of the founder of the theory of cross-cultural communication E. Hall [1] towards the need to teach cross-cultural communication as communication goes beyond language. It involves knowledge and understanding cultural contexts, traditions, values, lifestyles, mentalities, etc. Education has a purposeful and systematic way to provide such knowledge. This task is particularly urgent in modern Ukrainian contexts as an acute practical need for reorienting military education at the NGU in order to prepare future officers for performing their tasks in a multicultural space.

Considering the realities of the educational process at NANGU and the limitations that are due to the existing approved educational and professional training programs, our study presents a project that will require an interdisciplinary approach to building cross-cultural competence in future officers of NANGU. We rely on the recommendations for curriculum developers that were offered by a team of Cross-cultural Communication specialists and set out in the study of K. Puntey [2]. Practical needs of our study suggest the importance of results obtained from an analysis of existing modern theories and empirical data on cross-cultural competence and cross-cultural education and presented in the study carried out by L. B. Perry, L. Southwell [3].

Cross-cultural communication can be seen as a field of moral choices made by the individual. Thus, every situation of cross-cultural communication provides an opportunity to choose humanity and tolerance (known as ethics of possibility) that will ensure conflict-free interpersonal interaction [4]. In our study, it is fundamentally important to go beyond interpersonal interaction in cross-cultural communication as noted by I. Donnikova. The ethics of possibility and the situation of moral choice in a multicultural space must be considered in the context of social communication. The officer, as the head of the NGU unit, on the one hand, acts as a subject of social interaction, and, on the other hand, may find $\mathrm{him} /$ herself in a situation of moral choice in crosscultural communication.

\section{RESULTS AND DISCUSSION}

The National Guard of Ukraine is a special military formation vested with law enforcement functions. According to the Law of Ukraine "On the National
Guard of Ukraine", NGU units are also mandated to "participate in the restoration of law and order in case of interethnic and interfaith conflicts" [5]. Situations of cross-cultural contexts where NGU units perform their tasks are not provided.

In addition to the competencies of future NGU officers outlined in the state academic standard for specialties 253 Military Administration (by services and branches of the Armed Forces), 254 Organization of logistic support for troops (forces) [6] and adapted for NANGU graduates [7], regardless of specialty, following communicative competencies and relevant learning outcomes should be available (Table 1).

As we can see, there is a clearly fixed speech component of the communication process; attention is paid to the ability of future NGU officers for strategic communications. However, based on the definition given in the Military Doctrine of Ukraine (2015) [7], strategic communications, rather provide a set of information events in terms of state-society interaction and do not contain a component that would be associated with cross-cultural competence.

It can be assumed that the program learning outcome 08 (Table 1) indirectly contains a crosscultural component. According to the authors, the ability to understand the members of different professional groups, in particular, foreign servicemen, implies the ability to recognize the common and the different in culture, values, attitudes, appropriate behavioural reactions of social actors in a multicultural space. Thus, background knowledge can be interpreted as knowledge of cultures, traditions, customs in their diversity and interaction, as "a set of analytical and strategic abilities that expands the interpretive field of the member of cross-cultural communication" [8]. But these are only assumptions and interpretations.

The analysis suggests that, despite the sufficient number of communicative competencies, crosscultural aspects of social interaction and the corresponding cross-cultural competence of the NGU graduate is not recorded.

Domestic scientific and theoretical thought focuses on studying cross-cultural competence among students. At the same time, this competence is mainly reduced to the linguistic one, in particular, in the context of academic mobility. At the same time, a study of cross-cultural communication conducted by the cross-cultural research group for the European Association of Translators (EST) [9] proves that communicative deviations in the interactions of different cultures arise not so much because of 
linguistic differences but because of the specifics and differences of mentalities and views.

Table 1. Communicative competencies and learning outcomes of graduates of the National Academy of the National Guard of Ukraine outlined in educational and professional programs [7]

\begin{tabular}{|c|c|c|}
\hline $\begin{array}{l}\text { Specialty code and } \\
\text { name }\end{array}$ & Competency code and name & Program Learning Outcomes \\
\hline $\begin{array}{l}253 \\
\text { Military Administration } \\
\text { (by services and } \\
\text { branches of the Armed } \\
\text { forces) }\end{array}$ & $\begin{array}{l}\text { K08 Ability to communicate in the state } \\
\text { language (both oral and written } \\
\text { communication). } \\
\text { K09 Ability to communicate in a foreign } \\
\text { language. }\end{array}$ & $\begin{array}{l}\text { PR06 Communicate in the state language (both oral } \\
\text { and written communication). } \\
\text { PR08 Communicate and work in a team with } \\
\text { representatives of other professional groups at } \\
\text { different levels, with servicemen from foreign } \\
\text { countries considering specialized terminology, } \\
\text { knowledge and understanding their colleagues on } \\
\text { relevant issues. }\end{array}$ \\
\hline \multirow[b]{2}{*}{$\begin{array}{l}254 \text { Organization of } \\
\text { logistic support for } \\
\text { troops (forces) }\end{array}$} & $\begin{array}{l}\text { K08 Ability to com } \\
\text { language (both or } \\
\text { communication). }\end{array}$ & $\begin{array}{l}\text { PR06 Communicate in the state language (both oral } \\
\text { and written communication). }\end{array}$ \\
\hline & $\begin{array}{l}\text { K09 Ability to col } \\
\text { language. }\end{array}$ & $\begin{array}{l}\text { PR07 Communicate in a foreign language for } \\
\text { professional purposes. } \\
\text { PR08 Communicate and work in a team with } \\
\text { representatives of other professional groups at } \\
\text { different levels, with servicemen from foreign } \\
\text { countries considering specialized terminology, } \\
\text { knowledge and understanding their colleagues on } \\
\text { relevant issues. }\end{array}$ \\
\hline \multirow[t]{2}{*}{$\begin{array}{l}254 \text { Organization of } \\
\text { logistic support for } \\
\text { troops (forces) }\end{array}$} & $\begin{array}{l}\text { K25 Ability to organize and provide the } \\
\text { unit with linguistic support in the main } \\
\text { foreign language (level B2, STANAG 2) } \\
\text { and complementary foreign language } \\
\text { (level A1). }\end{array}$ & $\begin{array}{l}\text { PR25 Organize and provide linguistic support for the } \\
\text { unit using foreign languages (level B2 "Independent } \\
\text { User"/ level } 2 \text { "Functional", NATO STANAG } 6001 \text { for } \\
\text { main foreign language; level A1 "Beginner" for } \\
\text { complementary foreign language). }\end{array}$ \\
\hline & $\begin{array}{l}\text { K26 Ability to enable } \\
\text { communications of th }\end{array}$ & trategic communications of the unit. \\
\hline
\end{tabular}

At the same time, the formation of cross-cultural competence in future professionals in a civilian educational institution occurs through acquiring theoretical knowledge and directly practising crosscultural interaction, the subjects of which are students within the processes of internationalization of education. At the same time, international experience shows that providing students with opportunities for direct contact with a different culture does not imply cross-cultural competence. With no purposeful pedagogical support immersion in a foreign culture creates risks of perpetuating stereotypical thinking and racist views [10].

In Ukrainian military establishments of higher education cross-cultural interactions are almost never practised. The specificity of such institutions lies in a certain monoculturalism of the cadet environment. This is legally required. The existing practices of conducting joint exercises in the context of NATOUkraine cooperation, classes and trainings arranged by NATO member countries cannot involve all cadets. Classes with NATO instructors only indirectly provide an experience of cross-cultural communication, as the interaction occurs within the teacher-cadet model.
Thus, in the absence of everyday experience of direct cross-cultural communication, cross-cultural competence is built in future NGU officers only within the educational process and requires systematic and comprehensive work. At the same time, the target orientation of the process is important. At least three components should be considered, i.e. focus on the specifics of the functional tasks performed by NGU units, emphasis on legal decision making basic values of cross-cultural communication.

When implementing the objectives of the current study it is necessary to analyse the third component of target orientation. According to the authors, in building cross-cultural competence of future law enforcement officers the system-forming factors should be tolerance, mutual respect and tolerance towards people, their culture, religion, values, attitudes, etc. as well as recognition of equality (in legal and axiological dimensions) of each member in social interaction. These values must ensure the constructiveness of communication, regardless of the circumstances of a particular social interaction in a multicultural environment. They can be considered 
both as norms and principles of cross-cultural communication.

Tolerance implies recognition of the right of other people to be themselves, different from the expected stereotypes and attitudes. It appears as a prerequisite for the ability to lean into the realities and impartially assess the situation of social interaction when performing official and combat tasks.

For Ukraine, a tolerant attitude towards the person appears to be a rather difficult task. On the one hand, Ukraine identifies itself as a country belonging to European cultures [11]. Ukraine resides in a globalized space where interactions between different cultures (also those different from European cultures) are becoming more and more prominent. At the same time, there are still tangible consequences of secrecy, separation of Ukrainian society from foreign cultures through the long Soviet era when a monolithic Soviet culture, a unified lifestyle, human type led to building a sufficiently homogeneous social and cultural environments. This "heritage" bears atavism of dividing into "ours or theirs" like friends and foes, command and administrative management, mental attitudes that do not recognize pluralism, and social and cultural stereotypes that do not meet the requirements of modern democratic society and its values. All this is especially manifested in the Ukrainian power structures and service structures due to the inertia and closed nature of the military environment as such.

The complexity of the situation is demonstrated by the results of research conducted among students and cadets.

A study of cross-cultural tolerance conducted in student environments involved fifteen establishments of higher education scattered across eight regions of Ukraine. The results obtained from the research demonstrated "an average level of cross-cultural tolerance" $[12,90]$ and "an average level of crosscultural communication” $[12,91]$.

The authors of this article carried out a survey among cadets of National Academy of the National Guard of Ukraine that revealed today's cadet environment appears to be more closed, traditionally oriented, with insufficient cross-cultural tolerance.

The research was conducted as part of sessions on Philosophical and Sociological Foundations of Professional Military Activity. Research years: 2018/2019 and 2019/2020 academic years. Research participants: cadets of all NGU faculties (530 people). Research format: thought experiment. The purpose is to identify the extent to which the cadets are tolerant towards members of a different culture who live in Ukraine.
The cadets were placed in a simulated situation of cross-cultural communication where their NGU unit had to perform a task on ensuring public order. Under the conditions provided by the experiment, the research results proved that up to $86 \%$ of the participants resorted to certain cultural stereotypes, and, thus, demonstrated prejudice and bias in decisionmaking (Figure 1).

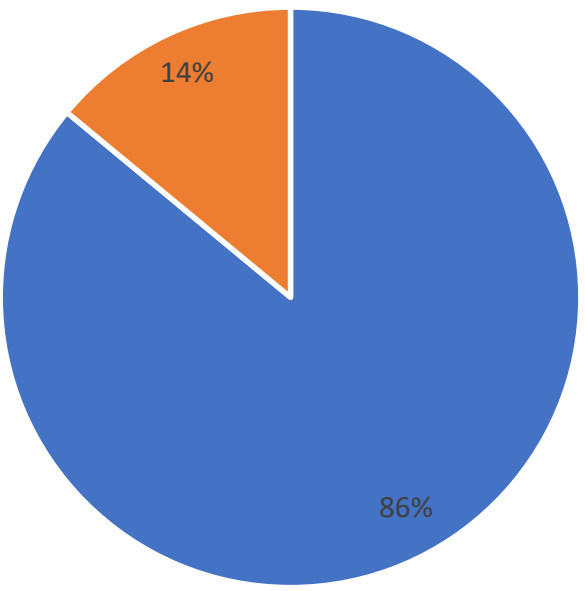

$$
\begin{aligned}
& \text { - A) stereotypes and prejudices dominate, zero } \\
& \text { tolerance - } 86 \% \\
& \text { - B) no stereotypes and prejudices found, } \\
& \text { tolerance is present - } 14 \%
\end{aligned}
$$

Figure 1 Distribution of respondents against the levels of tolerance revealed in the simulated situation of cross-cultural communication in the course of performing the task on ensuring public order.

Given that NANGU is the only institution of higher education in Ukraine that trains future officers of NGU, and that these officers will head units in all cities, oblasts and regions of Ukraine, this situation appears to be quite problematic and urgently needs to be addressed.

And then there is a problem of equality. The right to equality is recognized for everyone as a fundamental value of a democratic society. Equality is enshrined in the current Constitution of Ukraine, emphasizing that "everyone is entitled to all the rights and freedoms" (Article 21) [13]. Taking care of the sustainable development of society, Ukraine recognizes the prevention of discrimination as Task 2 within the framework of achieving Goal 10 "reduction of inequality" [14]. Thus, there is an urgent need to reorient future NGU officers from the traditional stereotypical perception of norms in cross-cultural 
interaction to purely legal democratic dimensions of the situation. This involves recognition and acceptance of everyone's right for equality at the deep level of the fundamental law.

Thus, the challenges associated with building a multicultural space in Ukraine require adjustments to the content of training programs for future law enforcement officers in the direction of developing their cross-cultural competence. According to the authors of the article, all social and humanitarian disciplines should be rethought conceptually in the direction of using cross-cultural optics.

We offer a project that will require an interdisciplinary approach towards building crosscultural competence on the basis of general social and humanitarian disciplines. Consider the specific goals, objectives and possible learning outcomes of each course with respect to the practical needs of professional military activities of NGU units (Table 2).

Table 2. Purpose, objectives and expected results after completing the course of socio-humanitarian disciplines on building cross-cultural competence.

\begin{tabular}{|c|c|c|c|}
\hline Disciplines & Purpose & Objectives & Expected result \\
\hline Philosophy & $\begin{array}{l}\text { cross-cultural awareness as } \\
\text { the basis of the individual } \\
\text { outlook in the age of } \\
\text { globalization }\end{array}$ & $\begin{array}{l}\text { - understanding the differences } \\
\text { between personal world views, } \\
\text { - original philosophies of national } \\
\text { cultures, } \\
\text { - finding out their role in the } \\
\text { development and formation of a } \\
\text { polylogical way of understanding } \\
\text { reality }\end{array}$ & \multirow{5}{*}{$\begin{array}{l}\text { When performing official and } \\
\text { combat tasks: } \\
\text { - deprivation of ethnocentric } \\
\text { views, stereotypical thinking and } \\
\text { behaviour; } \\
\text { - recognition of the equivalence } \\
\text { between domestic and foreign } \\
\text { cultures; } \\
\text { - overcoming socio-cultural and } \\
\text { ethno-cultural barriers; } \\
\text { - tolerance and equality as a } \\
\text { value basis of cross-cultural } \\
\text { communication; } \\
\text { - prevention of ethnocentrism, } \\
\text { racism and discrimination within } \\
\text { the context of cross-cultural } \\
\text { communication; } \\
\text { - equal dialogue / polylogue } \\
\text { within cross-cultural } \\
\text { communication }\end{array}$} \\
\hline $\begin{array}{l}\text { Ethics and } \\
\text { aesthetics }\end{array}$ & $\begin{array}{l}\text { cross-cultural values of } \\
\text { personality }\end{array}$ & $\begin{array}{l}\text { - knowledge of axiological } \\
\text { dimensions of cross-cultural } \\
\text { communication; } \\
\text { understanding of universal and } \\
\text { national values }\end{array}$ & \\
\hline \begin{tabular}{|l|} 
Religious \\
studies
\end{tabular} & $\begin{array}{l}\text { religious awareness as a } \\
\text { component of cross-cultural } \\
\text { competence }\end{array}$ & $\begin{array}{l}\text { - knowledge of world religions and } \\
\text { national religions in terms of their } \\
\text { diversity, ritual and cult specifics; } \\
\text { - knowledge of modern non- } \\
\text { traditional religions and cults }\end{array}$ & \\
\hline Sociology & $\begin{array}{l}\text { cross-culture as the basis of } \\
\text { optimal social communications }\end{array}$ & $\begin{array}{l}\text { - knowledge of global trends in } \\
\text { establishing a multicultural } \\
\text { environment, } \\
\text { - understanding ethno-cultural } \\
\text { factors of social stratification }\end{array}$ & \\
\hline Culturology & $\begin{array}{l}\text { cultural awareness as a } \\
\text { component of cross-cultural } \\
\text { competence }\end{array}$ & $\begin{array}{l}\text { - multiculturalism, dialogic / } \\
\text { polylogic forms of culture in the } \\
\text { modern world, } \\
\text { - dialogic cultures in the process } \\
\text { of building Ukraine as an } \\
\text { independent state, } \\
\text { - cultural identity in cross-cultural } \\
\text { communication. }\end{array}$ & \\
\hline
\end{tabular}

We consider it appropriate to use interactive methods when developing cross-cultural competence. The priority ones should include modelling situations of cross-cultural interaction in order to perform official and service-combat tasks, conducting focus groups, round tables and discussions, in particular, based on the results obtained from watching videos, writing reflective and critical essays, papers on social communication in multicultural environment, delivering speeches at scientific and practical conferences. At their own discretion, teachers select the most appropriate and effective methods of giving a lesson and its form taking into account the specifics of the tasks and the audience.

Promising directions in solving the issues covered in the study are deemed to be as follows:

- introduction of new general competence into the educational standards approved for NGU officers training, that is CCC, or cross-cultural competence;

- introduction of conceptual changes in all socialhumanitarian disciplines considering cross-cultural aspects; introduction of relevant disciplines in the syllabus; 
- use of interactive methods in the process of building cross-cultural competence;

- conducting training sessions and classes on developing cross-cultural competence in the teaching staff and management of the NANGU as part of the advanced training course;

- development of a special training course on the basics of cross-cultural communication in the age of globalization that will take place at NANGU;

- development of methodical recommendations on the basics of cross-cultural communication in the age of globalization for units and subdivisions of NGU.

\section{CONCLUSIONS}

Thus, the analysis suggests that the successful performance of official and combat tasks depends on the ability of law enforcement agencies to be unbiased and impartial, to prevent discrimination and violation of the principle of equality in terms of cross-cultural communication and under conditions of creating a multicultural space in Ukraine.

Professional training of future officers of the National Guard of Ukraine should include the development of cross-cultural competence as the ability to see common and different in various cultures, to overcome sociocultural and ethnocultural barriers based on the core cross-cultural values of tolerance and equality, and to instil these values in subordinates.

An interdisciplinary approach can provide a comprehensive development of cross-cultural competence in future NGU officers within the existing educational and professional programs. The unity of cross-cultural approach in teaching sociohumanitarian disciplines provides multifaceted development of the ability to overcome sociocultural and ethnocultural barriers, recognize the equality of various cultures, show tolerance and equality as a value basis of cross-cultural communication, and prevent ethnocentrism, racism within cross-cultural communication.

Effective in the formation of cross-cultural competence are the practices aimed at inclusion of all individuals in cross-cultural interaction since they appear to be interactive teaching methods and technologies in terms of higher education for the military.

Successful performance of these tasks requires changes in both conceptual approaches to training future officers of the NGU and overcoming obsolete personal attitudes and stereotypes.

\section{REFERENCES}

[1] E.T. Hall, The silent language, Doubleday, 1959, $240 \mathrm{p}$.

[2] K. Puntey, Deliberations on the development of an intercultural competence curriculum, Intercultural Education 27 (2016) 137-150. DOI: https://doi.org/10.1080/14675986.2016.11 45457

[3] L.B. Perry, L. Southwell, Developing intercultural understanding and skills: models and approaches, Intercultural Education 22 (2011) 453-466. DOI: https://doi.org/10.1080/14675986.2011.644948

[4] I. Donnikova, Moral Search in multicultural communication, Anthropological Measurements of Philosophical Research 14 (2018) 30-41. DOI: https://doi.org/10.15802/ampr.v0i14.150545

[5] Zakon Ukrainy Pro Natsionalnu hvardiiu Ukrainy (Law of Ukraine on the National Guard of Ukraine), 2020 . https://zakon.rada.gov.ua/laws/show/876-18

[6] Zatverdzhenni standarty vyshchoi osvity. Ministerstvo osvityinauky Ukrainy. 253 Viiskove upravlinnia (za vydamy zbroinykh syl) bakalavr; 254 Zabezpechennia viisk (syl) bakalavr (Approved Higher Education Standards. Ministry of Education and Science of Ukraine. 253 Military Administration (By Branches of Armed Forces) - Bachelor's Degree; 254 Organization of logistic support - Bachelor's Degree), 2020. https://mon.gov.ua/ua/osvita/vishaosvita/naukovo-metodichna-rada-ministerstvaosviti-i-nauki-ukrayini/zatverdzheni-standartivishoyi-osviti

[7] Ukaz Prezydenta Ukrainy Pro rishennia Rady natsionalnoi bezpeky i oborony Ukrainy vid 2 veresnia 2015 roku "Pro novu redaktsiiu Voiennoi doktryny Ukrainy" (The Decree of the President of Ukraine, On the decision of the National Security and Defence Council of Ukraine of September 2, 2015 "On the new version of the Military Doctrine of Ukraine" No. 555/2015),

2015. https://zakon.rada.gov.ua/laws/show/555/2015

[8] N. Todorova, Kros-kulturnyi menedzhment (Cross-cultural management), DonNTU, Donetsk, 2008, 330 p

[9] P. Anthony, On Translator Ethics. Principles for mediation between cultures, Benjamins Translation Library, 2012, 185 p. 
[10] F. Step, W. Bowles, D. Bridges, Developing intercultural competence and global citizenship through international experiences: academics' perceptions, Intercultural Education 24 (2013) 442-455. DOI:

https://doi.org/10.1080/14675986.2013.825578

[11] Zakon Ukrainy pro vnesennia zmin do Konstytutsii Ukrainy (shchodo stratehichnoho kursu derzhavy na nabuttia povnopravnoho chlenstva Ukrainy v Yevropeiskomu Soiuzi ta v Orhanizatsii Pivnichno-atlantychnoho dohovoru) (Law of Ukraine On Amendments to the Law of Ukraine (concerning the strategic course of the for acquiring full-fledged membership of Ukraine in the European Union and the North Atlantic Treaty Organization)), 2019. https://zakon.rada.gov.ua/laws/show/2680-19

[12] W. Zheyuan, Intercultural tolerance and intercultural communication: student survey, Continuing Professional Education: Theory and Practice (Series: Pedagogical Sciences) 1-2 (5051) (2017) 88-92. DOI: https://doi.org/10.28925/1609-8595.2017(12) 8892

[13] Konstytutsyia Ukrayni (Constitution of Ukraine), Kyiv, 2016, 96 p.

[14] Tsili staloho rozvytku: Ukraina: natsionalna dopovid (Sustainable Development Goals. Ukraine's national report), 2017. 